\title{
IDENTIFIKASI PERILAKU PASANGAN USIA SUBUR TERHADAP KEIKUTSERTAAN PROGRAM KELUARGA BERENCANA DENGAN PENDEKATAN TEORI PERILAKU YANG TERENCANAKAN (THEORY OF PLANNED BEHAVIOUR)
}

\author{
Anggie P. Putri \\ Program Studi D3 Keperawatan STIKES Mamba’ul 'Ulum Surakarta
}

\begin{abstract}
Attitude, Subjective Norm, Behaviour Control, Family Planning, Behaviour To Undergo Family Planning. This study aims to identify the influences of attitude, subjective norm, behaviour control and intention to attend Family Planning program using Theory of Planned Behaviour. The frame of this theory is tested to analize the influences of the constrution of this study, the understanding of attitude, subjective norm, behaviour control, intention to attend a program set by the government to controlling the population. Data collection was done by giving the questionnaire to 109 respondents who were undergoing Family Planning program in Jetiskarangpung, Sragen, Central Java Indonesia; but there are 100 valid questionnaires. The data is analized using T-test and then the variabels are analized using multiple Regression. The findings of this study shows that attitude (sig. 0,006), subjective norm (sig. 0,002), behaviour control (sig 0,012) gives significant influence of the intention to undergo the Family Planning program. This findings is aline with the philosphy within Theory of Planned Behaviour.
\end{abstract}

Keywords: Attitude, Subjective Norm, Behaviour Control, Family Planning, Behaviour To Undergo Family Planning.

Abstrak: Sikap, Norma Subyektif, Kontrol Perilaku, Keluarga Berencana (Kb), Perilaku Untuk Ber-Kb. Penelitian ini bertujuan untuk mengidentifikasi pengaruh sikap, norma subjektif, kontrol perilaku terhadap niat mengikuti program Keluarga Berencana (KB) dengan menggunakan Theory Of Planned Behaviour. Kerangka teori ini diuji serta dibangun untuk menguji pengaruh positif antar konstruksi penelitian, pemahaman pengaruh sikap, norma subjektif, kontrol perilaku, niat dan perilaku berKB. Pengumpulan data dilakukan dengan menyebarkan quesioner kepada 109 responden yang mengikuti program KB di Jetiskarangpung, Sragen, Jawa Tengah, Indonesia; tetapihanya 100 kuesioner dinyatakan valid. Data dianalisis dengan menggunakan uji T kemudian variabel-variabel yang ditetapakan dianalisis dengan Uji Regresi Berganda. Hasil penelitian ini menunjukkan bahwa sikap (sig. 0,006), norma subjektif (sig 0,002), kontrol perilaku(0,012); berpengaruh positif terhadap niat berobat $(0,00)$ serta dampaknya $(0,00)$ positif terhadap perilaku ber-KB. Hasil penelitian ini sejalan dengan Theory Of Planned Behaviour.

Kata Kunci: Sikap, Norma Subyektif, Kontrol Perilaku, Keluarga Berencana (Kb), Perilaku Untuk Ber-Kb. 


\section{PENDAHULUAN}

Indonesia masih menempati urutan lima besar sebagai negara dengan jumlah penduduk terbanyak. Per 30 Juni 2016, jumlah penduduk Indonesia sebanyak 257.912.349 jiwa. Sedangkan laju pertumbuhan penduduk berada di angka 1,49 persen (Kementrian Dalam Negeri, 2016). Laju pertumbuhan penduduk ini masih stagnan pada angka yang sama di tahun 2000, 16 tahun yang lalu (Sari dkk, 2010). Apabila kondisi ini tidak disiasati maka, baby boom tidak dapat terelakkan dalam jangka waktu 10 tahun ke depan.

Kependudukan menjadi masalah penting di Indonesia. Kependudukan merupakan segala hal yang berkaitan dengan jumlah, struktur, pertumbuhan, persebaran, pergerakan, penyebaran, kualitas dan kondisi kesejahteraan penduduk (Peraturan Pemerintah RI Nomor 87 Tahun 2014). Pengendalian kependudukan yang bermakna dibutuhkan untuk menyukseskan tujuan pembangunan global dan pembangunan lainnnya yang saling berkaitan.

Pemerintah

kebijakan-kebijakan yang mengatur tentang kependudukan. Tujuannya adalah untuk mewujudkan keseimbangan, keselarasan dalam perkembangan penduduk serta meningkatkan kualitas keluarga. Badan Kependudukan dan Keluarga Berencana Nasional (BKKBN) diamanahi oleh pemerintah untuk bertanggung jawab terhadap tercapainya indikator program kependudukan, KB dan pembangunan keluarga dalam bingkai Sasaran Rencana Pembangunan Jangka Menengah Nasional (RP JMN) tahun 2014-2019. Sasarannya adalah di tahun 2019 tercapai angka 2,28 anak per wanita per usia subur. Angka ini diperngaruhi salah satunya oleh penggunaan kontrasepsi atau keikutsertaan program Keluarga Berencana (KB).

Program KB menjadi salah satu kebijakan pemerintah Indonesia untuk menangani masalah kependudukan. Perwujudan dari program KB adalah dengan metode kontrasepsi, baik secara alami maupun menggunakan alat. Manfaat KB dirasakan secara langsung maupun tidak langsung bagi kesehatan ibu, bayi dan anak, kesehatan reproduksi, kehidupan seksual, kesejahteraan dan ketahanan keluarga. Akan tetapi, manfaat ini kurang mendapatkan perhatian yang maksimal dari kalangan masyarakat, terutama pasangan usia subur (PUS) (Agha, 2010).

Profil Kesehatan Indonesia (2015) menyebutkan jumlah PUS adalah 49.195.283. 29,155 juta (59.98\%) merupakan PUS yang mengikuti progam KB dengan semua cara; $58.99 \%$ menggunakan cara modern (AKDR, pil, suntik, susuk, MOP, MOW) dan 0.99\% menggunakan cara tradisional (meminum jamu atau ramuan, senggama terputus, sistem kalender).

Menurut data Susenas 2012-2015, sebagian besar PUS peserta program KB di Indonesia memilih metode kontrasepsi suntik (59.7\%) dan pil (20.71\%). Hal ini dikarenakan kedua metode tersebut mudah diterima oleh PUS kalangan ekonomi menengah, jangka penggunaan pendek dan lebih populer karena gencarnya iklan media massa (Irwansyah, 2016). Sedangkan, pengguna alat kontrasepsi jangka panjang panjang tercatat sebanyak $7.30 \%$ pengguna IUD, $6.21 \%$ pengguna susuk KB, $1.27 \%$ pengguna MOP dan kondom (Kementrian Kesehatan RI, 2015).

Keikutsertaan dan keaktifan PUS pada program KB dipengaruhi oleh 
seringnya peserta $\mathrm{KB}$ terpapar informasi tentang $\mathrm{KB}$, kemudahan dalam menjangkau fasilitas kesehatan yang mendukung pelaksanaan $\mathrm{KB}$, dukungan dari pasangan, motivasi dari orang sekitar serta faktor kesehatan suami-istri yang tidak dapat dikesampingkan kepentingannya (Bailey, 2014). Faktor internal dari individu menjadi motor dalam terealisasinya keberhasilan program $\mathrm{KB}$ yang berkelanjutan. Hal ini tidak dapat dipisahkan dari kebiasaan perilaku pada peserta KB.

Menilik kajian literatur terkait pentingnya keikutsertaan PUS dalam program $\mathrm{KB}$ untuk mendukung terwujudnya pembangunan nasional yang merata, maka peneliti tertarik untuk mengidentifikasi perilaku PUS terhadap keikutsertaan program KB dengan pendekatan Teori Perilaku yang Terencanakan (Theory of Planned Behavior).

Peneliti merumuskan empat poin terkait fenomena tersebut, yaitu: 1) bagaimana pengaruh sikap PUS terhadap niat keikutsertaan program $\mathrm{KB}, 2$ ) bagaimana pengaruh norma subjektif PUS terhadap niat keikutsertaan program KB, 3) bagaimana pengaruh kontrol perilaku PUS terhadap niat keikutsertaan program $\mathrm{KB}$, 4) bagaimana pengaruh niat PUS terhadap keikutsertaan program KB.

\section{METODE PENELITIAN Strategi penelitian}

Penelitian ini dilakukan untuk menguji hipotesis dengan maksud membenarkan atau memperkuat hipotesis dengan harapan yang pada akhirnya dapat memperkuat teori yang dijadikan pijakan.

Jenis penelitian yang digunakan adalah explanatory research. Maltby (2010) menyatakan bahwa penelitian ekplanatori merupakan penelitian yang bersifat menjelaskan, artinya penelitian ini menekankan pada hubungan antar variabel penelitian dengan menguji hipotesis, uraiannya mengandung deskripsi tetapi fokusnya terletak pada hubungan antar variabel.

Peneliti menggunakan uji ANOVA untuk menganalisis adakah pengaruh variabel independen dan variabel dependen dalam penelitian ini.

\section{HASIL PENELITIAN \\ Hasil Analisis Data}

Pengujian regresi berganda dalam penelitian ini digunakan untuk mengetahui pengaruh dari variabel sikap, norma subjektif, kontrol perilaku, niat dan perilaku erhadap keikutsertaan PUS dalam program KB.

Tabel 1

\section{Hasil Analisis Regresi - Persamaan 1}

\begin{tabular}{lccccc}
\hline \multicolumn{1}{c}{ Ket. } & $\begin{array}{c}\text { Unstandardized } \\
\text { Coefficients }\end{array}$ & $\begin{array}{c}\text { Standar } \\
\text { dized } \\
\text { Coeffici } \\
\text { ents }\end{array}$ \\
\cline { 2 - 6 } & B & $\begin{array}{c}\text { Std. } \\
\text { Error }\end{array}$ & Beta & t & Sig. \\
\hline (Constant) &,- 251 &, 489 & &,- 512 &, 610 \\
Sikap_X1 &, 333 &, 118 &, 286 & 2,833 &, 006 \\
Norma &, 358 &, 112 &, 305 & 3,192 &, 002 \\
Subjektif_ &, 273 &, 107 &, 254 & 2,553 &, 012 \\
X2 & & & & & \\
Kontrol & & & & & \\
Perilaku_X3 & & & & & \\
\hline
\end{tabular}

Dari persamaan regresi di atas dapat dijelaskan bahwa variabel sikap (X1), norma subyektif (X2) dan kontrol perilaku (X3) mempunyai pengaruh positif atau mempunyai pengaruh searah dengan niat keikutsertaan KB (Y1). Pengaruh norma subjektif sebagai pengaruh terbesar yaitu $30,5 \%$, dibanding dengan variabel lain yaitu sikap sebesar $28,6 \%$ dan variabel kontrol perilaku sebesar $25,4 \%$. 
Tabel 1 juga menunjukkan bahwa nilai probabilitas variabel sikap, norma subjektif, kontrol perilaku dibawah nilai yang diisyaratkan yaitu 0,05 . Sehingga hasil penelitian ini mendukung hipotesis yang menyatakan bahwa sikap berpengaruh positif terhadap niat keikutsertaan ber-KB (H1), norma subjektif berpengaruh positif terhadap keikutsertaan ber-KB (H2), dan Kontrol Perilaku berpengaruh positif terhadap keikutsertaan ber-KB (H3).

\section{Tabel 2}

Hasil Analisis Regresi - Persamaan II

\begin{tabular}{cccccc}
\hline \multirow{2}{*}{ Ket. } & $\begin{array}{c}\text { Unstandardized } \\
\text { Coefficients }\end{array}$ & $\begin{array}{c}\text { Standa } \\
\text { rdized } \\
\text { Coeffi } \\
\text { cients }\end{array}$ & & \\
\cline { 2 - 6 } & $\mathrm{B}$ & $\begin{array}{c}\text { Std. } \\
\text { Error }\end{array}$ & Beta & t & Sig. \\
\hline (Constant) & 2,033 &, 349 &, 662 & 5,820 &, 000 \\
Niat (Y1) &, 611 &, 070 & , & & \\
\hline
\end{tabular}

Dari persamaan regresi tersebut, dapat dijelaskan bahwa niat berobat (Y1) Mempunyai pengaruh positif atau mempunyai pengaruh searah dengan perilaku berobat (Y2). Pengaruh niat berobat memiliki pengaruh yang cukup besar terlihat dari pengaruh yang dtimbulkan lebih dari $50 \%$ atau dalam analisis sebesar $66,2 \%$.

Tabel 2 menggambarkan bahwa nilai probabilitas variabel niat keikutsertaan ber-KB dibawah nilai yang diisyaratkan yaitu 0,05 . Sehingga hasil penelitian ini mendukung hipotesis yang menyatakan bahwa niat keikutsertaan ber$\mathrm{KB}$ berpengaruh positif terhadap perilaku keikutsertaan ber-KB (H4).

\section{Uji Signifikansi Simultan}

Uji ini menggunakan ANOVA untuk menerangkan apakah variabel independen dalam model memiliki pengaruh simultan atau bersama-sama terhadap variabel dependen.

\section{a. Uji signifikansi simultan variabel sikap, norma subyektif dan kontrol perilaku terhadap niat}

Tabel 3

Uji Pengaruh Simultan Persamaan 1

\begin{tabular}{cccccc}
\hline Keterangan & $\begin{array}{c}\text { Sum of } \\
\text { Squares }\end{array}$ & df & $\begin{array}{c}\text { Mean } \\
\text { Square }\end{array}$ & F & Sig \\
\hline Regression & 52,774 & 3 & 17,591 & 38,810 &, $000^{\mathrm{a}}$ \\
Residual & 43,514 & 96 &, 453 & & \\
Total & 96,288 & 99 & & & \\
\hline
\end{tabular}

Hasil uji ANNOVA atau uji $\mathrm{F}$ diperoleh nilai $\mathrm{F}$ hitung sebesar 38,810 dengan probabilitas 0,000 . Karena nilai probabilitas jauh dibawah nilai diisyaratkan yaitu 0,05 , maka model regresi ini dapat digunakan untuk memprediksi niat keikut sertaan dalam program $\mathrm{KB}$ atau dapat dikatakan variabel sikap, norma subjektif, kontrol perilaku secara simultan atau bersama-sama berpengaruh terhadap niat.

\section{b. Uji signifikansi simultan variabel niat terhadap perilaku}

\section{Tabel 4}

Uji Pengaruh Simultan Persamaan II

\begin{tabular}{lccccc}
\hline Keterangan & $\begin{array}{c}\text { Sum of } \\
\text { Squares }\end{array}$ & df & $\begin{array}{c}\text { Mean } \\
\text { Square }\end{array}$ & F & Sig \\
\hline Regression & 35,963 & 1 & 35,963 & 76,520 &, $000^{\mathrm{a}}$ \\
Residual & 46,058 & 98 &, 470 & & \\
Total & 82,021 & 99 & & & \\
\hline
\end{tabular}

Uji ANNOVA atau uji $F$ diperoleh nila $F$ hitung sebesar 76,520 dengan probabilitas 0,000 . Karena nilai probabilitas jauh dibawah nilai diisyaratkan yaitu 0,05 ; maka model regresi ini dapat digunakan untuk memprediksi perilaku keikutsertaan program $\mathrm{KB}$ atau dapat dikatakan bahwa variabel niat keikutsertaan program $\mathrm{KB}$ 
berpengaruh terhadap perilaku keikutsertaan program KB.

\section{Koefisien Determinasi}

Adjusted $\mathrm{R}$ square atau uji koefisien determinasi ditujukan untuk mengukur seberapa jauh kemampuan model dalam menerangkan variasi variabel dependen.

1. Pengaruh variabel sikap, norma subyektif dan kontrol perilaku terhadap niat

\section{Tabel 5}

\section{Koefisien Determinasi Persamaan 1}

\begin{tabular}{ccccc}
\hline $\begin{array}{c}\text { Keterang } \\
\text { an }\end{array}$ & $\mathbf{R}$ & $\begin{array}{c}\mathbf{R} \\
\text { Square }\end{array}$ & $\begin{array}{c}\text { Adjuste } \\
\mathbf{d} \\
\mathbf{R} \\
\text { Square }\end{array}$ & $\begin{array}{c}\text { Std. Error } \\
\text { of } \\
\text { the } \\
\text { Estimate }\end{array}$ \\
\hline 1 &, 74 &, 548 &, 534 &, 67325 \\
\hline & $0^{\mathrm{a}}$ & & & \\
\hline
\end{tabular}

Koefisien determinasi atau nilai adjusted $R^{2}$ sebesar 0,534 . Hal ini berarti sikap, norma subjektif dan kontrol perilaku hanya mampu menjelaskan variasi niat sebesar $53,4 \%$ sedangkan sisanya dipengaruhi oleh faktor lain yang tidak masuk dalam model penelitian.

\section{Pengaruh niat terhadap niat perilaku} Tabel 6

Koefisien Determinasi II

\begin{tabular}{ccccc}
\hline $\begin{array}{c}\text { Keterang } \\
\text { an }\end{array}$ & $\mathbf{R}$ & $\begin{array}{c}\mathbf{R} \\
\text { Square }\end{array}$ & $\begin{array}{c}\text { Adjuste } \\
\mathbf{d} \\
\mathbf{R} \\
\text { Square }\end{array}$ & $\begin{array}{c}\text { Std. Error } \\
\text { of } \\
\text { the } \\
\text { Estimate }\end{array}$ \\
\hline 1 & $\begin{array}{c}6 \\
\mathrm{a}\end{array}$ &, 438 &, 433 &, 68555 \\
\hline
\end{tabular}

Tabel 6 menggambarkan bahwa koefisien determinasi atau nilai adjusted $R^{2}$ sebesar 0,433 . Hal ini berarti niat keikutsertaan program KB mampu menjelaskan variasi perilaku PUS dalam keikutsertaannya di program KB t sebesar $43,3 \%$ sedangkan sisanya dipengaruhi oleh faktor lain yang tidak masuk dalam model penelitian ini.

\section{PEMBAHASAN}

Hasil analisis menunjukkan bahwa nilai standardized coeficients variabel sikap sebesar $0,286(28,6 \%)$ dengan nilai signifikansi 0,006 ; norma subyektif sebesar $0,305(30,5 \%)$ dengan nilai signifikansi 0,002 ; dan kontrol perilaku $0,254(25,4 \%)$ dengan nilai signifikansi 0,012; terhadap niat PUS mengikuti program KB. Analisis ketiga variabel tersebut menunjukkan bahwa nilai signifikansi yang didapatkan berada di bawah nilai signifikansi yang diisyaratkan yaitu sebesar 0,05 .

Pada uji regresi persamaan 1 dengan nilai probabilitas variabel sikap, norma subjektif, dan kontrol perilaku dibawah nilai yang disyaratkan yaitu 0,05 dan dilihat dari uji ANOVA atau uji $\mathrm{F}$ diperoleh nilai $\mathrm{F}$ hitung sebesar 38,810 dengan probabilitas 0,000 . Karena nilai probabilitas jauh dibawah nilai yang disyaratkan yaitu 0,05 maka dapat dikatakan bahwa variabel sikap, norma subjektif dan kontrol perilaku secara simultan atau bersama-sama berpengaruh terhadap niat PUS mengikuti program KB. Perhitungan tersebut mendukung diterimanya hipotesis $(\mathrm{H} 1, \mathrm{H} 2$ dan $\mathrm{H} 3)$ yang bermakna bahwa terdapat pengaruh positif dari sikap, norma subyektif dan kontrol perilaku terhadap niat responden dalam keikutsertaannya pada program KB.

Sikap, norma subyektif dan kontrol perilaku sesuai dengan teraplikasinya Theory of Planned Behavior sebagai prediktor dari niat berobat pasien ke suatu pelayanan kesehatan (Ajzen, 2009). Pernyataan tersebut memperkuat hasil penelitian yang penulis peroleh.

Analisis tentang sikap dan norma subyektif dalam hubungannya dengan niat 
juga didapatkan pada penelitian yang berjudul Attitudes, Subjective Norms and Perceived Behavioral Control: Critical Care Nurses' Intentions to Provide Culturally Congruent Care to Arab Muslims. Hasil penelitian menunjukkan terdapat hubungan positif dan signifikan antara sikap para perawat gawat darurat dan norma subyektif dengan niat untuk memberikan pelayanan keperawatan yang sesuai dengan kultur atau budaya pasien Muslim Arab (Marrone, 2005). Hal ini selaras dengan hasil penelitian ini.

Penulis menganalisis bahwa dari ketiga faktor yang mempengaruhi niat, seperti sikap, norma subyektif dan kontrol perilaku; ditemukan bahwa yang memiliki pengaruh paling kuat dari ketiganya adalah norma subyektif yaitu sebesar 30,5 $\%$. Hasil ini sejalan dengan penelitian yang dilakukan oleh Knabe (2012), “...of the three, subjective norms was found to be strongest predictors of intention...".

Dalam penelitian ini, dukungan dari pasangan yang masuk dalam norma subyektif dimana memberikan dampak pada kesadaran pasangan akan pentingnya mengikuti program KB. Metode kontrasepsi yang digunakan tergantung kesadaran dan saling dukung diantara pasangan (Ezaenolue et al., 2015). Termasuk peran dari petugas kesehatan yang menyarankan PUS untuk mengikuti program KB menjadikan keyakinan PUS untuk turut serta pada program KB (Fagan et al., 2017 \& Sari dkk., 2010).

Pengaruh positif atau searah dapat dilihat dari nilai standardized coeficients niat keikutsertaan program KB sebesar 0,662 yang berarti niat keikutsertaan program KB berpengaruh $66,2 \%$ terhadap perilaku keikutsertaan program $\mathrm{KB}$ di Desa Jetis Karangpung, Sragen. Hal ini menunjukkan bahwa ada pengaruh yang besar karena mempunyai nilai $\mathrm{t}$ diatas $50 \%$, sedangkan pengaruh signifikan sebesar 0,000 jauh dibawah yang disyaratkan yaitu 0,005 . Hal ini juga mendukung hipotesis (H4) yang menyatakan bahwa niat keikutsertaan program $\mathrm{KB}$ berpengaruh positif terhadap perilaku berobat.

Pada uji regresi persamaan 2 dengan nilai probabilitas variabel niat berobat dibawah nilai yang disyaratkan yaitu 0,05 dan dilihat dari uji ANOVA atau uji $\mathrm{F}$ diperoleh nilai $\mathrm{F}$ hitung sebesar 76,520 dengan probabilitas 0,000. Karena nilai probabilitas jauh dibawah nilai yang disyaratkan yaitu 0,05 .

Hasil yang didapatkan dari penelitian ini juga ditemukan dalam penelitan Singh et al. (2013). Penelitian tersebut mengemukakan bahwa selain didapat pengaruh signifikan antara sikap, norma subyektif dan kontrol perilaku terhadap niat, ternyata juga didapatkan pengaruh yang signifikan antara niat berperilaku dengan perilaku terhadap suatu kegiatan. Hal ini sejalan dengan penelitian yang dilakukan penulis tentang niat PUS untuk mengikuti program KB di Desa Jetiskarangpung, Sragen.

Adanya niat dalam keikutsertaan dalam program KB yang timbul baik dari diri sendiri maupun persetujuan pasangan memberikan signifikansi dalam perilaku keikutsertaan program $\mathrm{KB}$, walaupun salah satunya, harus mengikuti aturan dalam metode kontrasepsinya. Penjelasan dalam penelitian ini sejalan dengan penelitian Agha (2010) terkait kampanye perubahan perilaku untuk keikutsertaan program KB, dimana niat positif dalam keikutsertaan program family planning memiliki dampak pada perubahan perilaku PUS untuk keikutsertaan program KB. 
Pernyataan tersebut dilihat dari nilai koefisien determinasi atau nilai adjusted $R^{2}$ sebesar 0,534. Kecil nilai adjusted $R^{2}$ menandakan masih ada variabel lain di luar penelitian yang nilainya lebih besar dari pada ketiga variabel tersebut misalnya dapat berupa strategi promosi yang digunakan oleh petugas kesehatan atau pemerintah, lokasi tempat tinggal, melakukan propaganda atau promosi minimal 1 bulan sekali, pertemuan lintas sektoral untuk mendapatkan permasalahan yang dirasakan oleh PUS yang berkeinginan untuk mengikuti rogram KB agar mendapatkan bahan dan masukan dalam menyelesaikan prioritas masalah yang bisa diselesaikan.

Azmat et al. (2015) menyatakan bahwa terdapat faktor-faktor prediksi dalam keikutsertaan program KB. Penggunaan kontrasepsi dipengaruhi oleh seberapa besar terpaparnya informasi dan follow up dari tenaga kesehatan terkait. Kondisi ini memiliki pengaruh signifikan pada permintaan PUS untuk ikut serta dalam program KB. Fenomena ini dapat mendukung penjelasan bahwa terdapat faktor lain yang memiliki pengaruh signifikan dimana belum masuk dalam model penelitian ini.

Niat responden untuk mengikuti program KB dapat dilihat dari nilai koefisien determinasi atau nilai adjusted $\mathrm{R}^{2}$ sebesar 0,433 . Besarnya nilai adjusted $\mathrm{R}$ mendukung teori yang mengatakan bahwa $\mathrm{B}=\mathrm{BI}$ (Behaviour/Perilaku berobat dapat berhubungan dengan Behaviour Intens atau Niat Berobat).

Akses kemudahan menjangkau fasilitas yang mendukung terlaksananya program $\mathrm{KB}$, terutama yang menggunakan alat kontrasepsi kontinu, menjadi hal penting dalam keikutsertaan program KB.
Dalam penelitian kohort-nya, Bailey (2014) menggambarkan adanya variasi dalam keikutsertaan PUS dalam program KB. Faktor keterjangkauan dan paparan informasi akan program $\mathrm{KB}$ mendukung keberlangsungan keikutsertaan PUS dalam program KB. Selain itu, dampak jangka menengah dan panjang dari $\mathrm{KB}$ pada pengentasan masalah kemiskinan dijadikan sorotan pada penelitiannya (Bailey et al., 2014).

\section{KESIMPULAN DAN SARAN}

Penelitian ini menunjukkan bahwa adanya pengaruh yang signifikan antara sikap, norma subyektif dan kontrol perilaku terhadap niat keikutsertaan program KB. Selanjutnya, niat keikutsertaan program KB ternyata memiliki pengaruh yang signifikan pula terhadap perilaku masyarakat untuk keikutsertaan program KB di Jetiskarangpung, Sragen, Jawa Tengah.

Populernya penggunaan metode kontrasepsi jangka pendek, seperti suntik dan pil memiliki peluang yang lebih besar untuk terjadinya putus pakai karena masalah pelayanan ulangan. Kondisi ini didukung oleh masalah geografis dimana sebagian dari peserta KB tinggal di wilayah yang kurang dijangkau oleh pelayanan KB secara menyeluruh (Singh et al., 2016). Padahal di sisi lain, tujuan penggunaan kontrasepsi dilihat dari efektivitasnya, trend penggunaan kontrasepsi jangka panjanglah yang diharapkan (Susenas, 2015). Kondisi ini memberikan gambaran atas fenomena keikutsertaan pasangan usia subur pada wilayah dengan lokasi cukup jauh dari pusat pemerintahan, yaitu di Jetiskarangpung, Sragen, Jawa Tengah.

Secara praktis, penelitian ini dapat diaplikasikan untuk peningkatan motivasi 
keikutsertaan program KB guna mendukung kebijakan pemerintah.

Peneliti juga menyarankan bahwa untuk penelitian selanjutnya, sebaiknya tidak hanya terbatas pada variabel yang terdapat pada Theory of Planned Behaviour. Alasannya, karena masih banyak variabel lain yang mungkin lebih sesuai dan lebih dominan ditujukan pada penelitian mengenai niat dan perilaku dalam keikutsertaan program KB di Jetiskarangpung, Sragen, Jawa Tengah.

Penelitian lebih lanjut diharapkan lebih memperhatikan niat dan perilaku keikutsertaan program KB yang ada di luar item pertanyaan pada penelitian ini misalnya niat berobat pasien timbul dikarenakan strategi sosialisasi dan motivasi yang baik.

\section{DAFTAR RUJUKAN}

Agha, S. (2010). Intentions to use contraceptive in Pakistan: Implications for behavior change campaigns. BMC Public Health, 10 (450), 1-13. doi: 10.1186/14712458-10-450.

Ajzen, I. (2008). Attitudes, Personality, and Behavior. Milton Keynes, UK: Open University Press.

Ajzen, I. (2009). The Theory of Planned Behavior. Organizational Behavior and Human Decision Processes. 50 (3) $179-211$.

Azmat, S.K., Ali, M., Ishaque, M., Mustafa, G., Hameed, W., Khan, O.F., Abbas, G., Temmerman, M., Munroe, E. (2015). Assessing predictors of contraceptive use and demand for family planning services in underserved areas of Punjab province in Pakistan: result of a cross-sectional baseline survey. Reproductive Health, 12
(25), 1-10. doi: 10.1186/s12978015-0016-9

Bailey, M.J. (2014). Fifty years of family planning: New evidence on the long-run effects of increasing access to contraception. Brookings Pap Econ Act. 2013, Spring: 341409. doi: 10.1353/eca.2013.0001

Bailey, M.J., Malkova, O., Norling, J. (2014). Do family planning programs decrease poverty? Evidence from public census data. CESifo Econ Study., 60 (2), 312337. doi: 10.1093/cesifo/ifu011

Fagan, T., Dutta, A., Rosen, J., Olivetti. A., Klien, K. (2017). Family planning in the context of Latin America's universal health coverage agenda. Global Health: Science ad Practice, 5 (3), 382398. Doi: 10.9745/GHSP-D-1700057

Irwansyah, Ekawati, R., Ernungtyas, N.F. (2016). Efek iklan televisi program keluarga berencana. Jurnal Komunikasi, 8(1),12-24.

Kementrian Dalam Negeri. (2016). Riset kependudukan kaitannya dengan perekaman data penduduk.

Knabe, Ann Peru. (2012). Applying Ajzen's Theory of Planned Behavior to a study of online course adoption in public relations education. A Dissertation. http://epublications.marquette.edu/ dissertations_mu/186

Maltby, J., Williams, G.A., McGarry, J., \& Liz D. (2010). Research methods for nursing and healthcare. England: Pearson.

Marrone, Stephen Richard. (2005). Attitudes, subjective norms, and perceived behavioral control: Critical care nurses' intentions to 
provide culturally congruent care to Arab Muslims. Research Report. Columbia University Teachers College (unpublished).

Mboane, R., Bhatta, M.P. (2015). Influence of a husband's healthcare decision making role on a woman's intention to use contraceptives among Mozambican women. Reproductive Health, 12(36), 1-8. doi: 10.1186/s12978-015-0010-2

Sari, S.K., Suryani, E.S., Handayani, R. (2010). Hubungan konseling keluarga berencana $(\mathrm{KB})$ dengan pengambilan keputusan pasangan usia subur (PUS) dalam penggunaan alat kontrasepsi. Jurnal Ilmiah Kebidanan, 1(1),3747.

Singh, A., Singh, K.K., Verma P. (2016). Knowledge, attitude and practice GAP in family planning usage: An analysis of selected cities of Uttar Pradesh. Contraception and Reproductive Medicine, 1(2) 1-10. doi: 10.1186/s40834-016-0031-4 